\title{
Teachers' Perception and Opinions Regarding the Communication Skills of School Administrators ${ }^{*}$
}

\author{
Soner DOĞAN ${ }^{* *}$
}

\author{
Şahin ÇETİN ${ }^{* * *}$
}

\author{
Osman KOÇAK ${ }^{* * * *}$
}

Received: 16 May 2014

Accepted: 22 April 2015

\begin{abstract}
The aim of this study is to evaluate communication skills of school administrators according to the perceptions and opinions of the branch teachers working in secondary schools. In the study, the explanatory pattern involving the quantitative and qualitative methods was used. Quantitative part of the study was designed in the screening model. The quantitative data was collected from 211 teachers working in the province of Sivas through the "Scale for Communication Skills of School Principals". The qualitative part of the study, however, was conducted in accordance with the case study design. The qualitative data, on the other hand, was obtained from 20 teachers working in the province of X through the semi-structured interview form. Quantitative findings of the study show that the teachers perceive the communication skills of school administrators highly positive whereas they, in general, they find the communication skills of school administrators unsatisfying according to the qualitative findings. In this context, we can say that the qualitative findings do not support the quantitative findings, and accordingly, the school administrators have problems in their communication skills.
\end{abstract}

Keywords: communication, communication skills of school administrators, branch teachers

\section{Extended Abstract}

Purpose and Significance: The most important element that starts the process of communication and determines the structure and nature of the communication is the school principal (Celep, 2000). The school principal, who has the characteristic of human resources manager in a school organization, is also a communication leader. An organization without communication is not possible. Yet, it is also impossible to have a common goal in a school organization without communication, to achieve this goal and to coordinate human resources of the school organization (Karsl1, 2006). Thus, having an efficient communication network in schools which is an educational organization is almost a necessity.

Analyzing the relevant literature, the studies on the communication skills of school administrators in educational institutions are not rare (Argon \& Zafer, 2009; Ärlestig, 2007; Aslanargun \& Bozkurt, 2012; Aydoğan \& Kaşkaya, 2010; Doğan, Uğurlu, Y1ldırım \& Karabulut, 2014; Durgun, 2011; Halawah, 2005; Myran, Sanzo \& Clayton, 2011; Özan, 2006; Rowicki, 1999; Şimşek \& Altınkurt, 2009). As is seen, the

\footnotetext{
* The quantitative findings of this article were taken from the master's thesis of Osman Koçak.

${ }^{* *}$ Corresponding Author: Assoc. Prof. Dr., Cumhuriyet University, Sivas, Turkey, snr312@gmail.com

**** Dr., Military Academy, Ankara, Turkey, scetin93@gmail.com

***** Teacher, Ministry of National Education, Sivas, Turkey, kocak.2012@hotmail.com
}

\section{Citation Information}

Doğan, S., Çetin, Ş., \& Koçak, O. (2016). Okul yöneticilerinin iletişim becerilerine ilişkin öğretmenlerin algı ve görüşleri. Kuramsal Eğitimbilim Dergisi [Journal of Theoretical Educational Science], 9(1), 57-84. 
communication skills of school administrators have been, generally, studied with quantitative methods. In this regard, no study in the literature was found to be based on mixed methods in which the perceptions of the branch teachers working in secondary schools on the communication skills of school administrators were evaluated with both qualitative and quantitative methods. Through this different perspective brought to the study, the communication skills of school administrators were evaluated both at the level of teachers' perceptions through the "Scale for Communication Skills of School Principals" and as based on the opinions of teachers with open-ended questions, more reliable conclusions were reached on the subject by comparing the quantitative and qualitative findings. The study, in this respect, differs from other studies conducted on the communication skills of school administrators and gains importance for bringing a new perspective to the literature. Within this scope, the aim of the study is to evaluate the communication skills of school administrators according to the perceptions and opinions of the branch teachers working in secondary schools.

Methods: In the study, the explanatory pattern which includes the quantitative and qualitative methods was used. Quantitative part of the study was designed in the screening model. The quantitative data was collected from 211 teachers working in the province of Sivas through the "Scale for Communication Skills of School Principals". In the analysis of the quantitative data, the standard deviation and arithmetic mean values were used. The qualitative part of the study, however, was conducted in accordance with the case study design. The qualitative data, on the other hand, was obtained from 20 teachers working in the province of $X$ through the semi-structured interview form. In the analysis of qualitative data, the content and descriptive analyses were used.

Result: In the study, when evaluated by considering the scale for communication skills of school administrators and the point range sub-dimensions of which is encoded according to the options (SKPA), it has been observed that teachers perceive the dimension of empathic thinking, knowledge transfer and positive attitudes at "I totally agree" level, the dimension of unbiasedness and planning at "I agree" level and the scale for communication skills of school administrators at "I totally agree" level in total. In addition, it has been found that the average of the teachers' perception on the communication skills of school administrators varies within the range of ( $\bar{x}=4.21)$ and $(\bar{x}=4.40)$ according to their seniority, branch and gender variables.

In the qualitative findings of the study, the responses obtained from the open-ended questions posed to teachers were examined following their categorization as "satisfying", "partially satisfying" and "unsatisfying". Accordingly, the teachers evaluated the communication skills of school administrators, in general, "satisfying" at a rate of 35\%, their empathic thinking skills "satisfying" at a rate of 30\%, their transfer of knowledge skills "satisfying" at a rate of $45 \%$ and their unbiasedness skills "satisfying" at a rate of $40 \%$. 
Discussion and Conclusions: However, the fact that the total score obtained from the scale for the communication skills of school administrators is at the level of "I totally agree" shows that the teachers perceive the communication skills of school administrators highly "satisfying" in total. Some consequences supporting this finding has also been found in the literature (Çelik, 2008; Çelik, 2013; Çetinkaya, 2011; Çetinkaya, 2012; Fidan, 2013; Lal, 2012; Önsal, 2012; Şahin, 2007; Sevinç, 2013; Şimsek, 2003; Şimşek \& Altınkurt, 2009). The teachers' perceptions on the communication skills of school administrators were found at "I totally agree" level in all variables. However, in the relevant literature, some research findings which do not overlap with this result has also been found (Bektaş, 2010; Cesur, 2009; Çalışgan, 2006; Çelik, 2008; Çetinkaya, 2012; Sevinç, 2013; Şimşek \& Altınkurt, 2009; Tek, 2008).

While no qualitative study on the communication skills of school administrators was encountered in the literature, within the quantitative studies on this subject, only the studies conducted by Gürsun (2007) and Durgun (2011) were found to have findings in support of qualitative results of this study. 


\section{Okul Yöneticilerinin İletişim Becerilerine İlişkin Öğretmenlerin Algı ve Görüşleri*}

Soner DOĞAN*

\author{
Şahin ÇETİN ${ }^{* * *}$
}

Osman KOÇAK ${ }^{* * * *}$

Makale Gönderme Tarihi: 16 Mayıs 2014

Makale Kabul Tarihi: 22 Nisan 2015

ÖZ: $\mathrm{Bu}$ araştırmanın amacı, okul yöneticilerinin iletişim becerilerini ortaokullarda görev yapan branş öğretmenlerinin algılarına ve görüşlerine göre değerlendirmektir. Araştırmada, nicel ve nitel yöntemleri içerisine alan açıklayıcı (explanatory) desen kullanılmıştır. Araştırmanın nicel bölümü tarama modelinde desenlenmiştir. Nicel veriler, X ilinde görev yapan 211 öğretmenden, "Okul müdürlerinin İletişim Becerileri ölçeği” aracilığıyla toplanmıştır. Araştırmanın nitel bölümü ise durum çalışması desenine uygun olarak yürütülmüştür. Veriler, nicel bölümde kullanılan ölçeğin içeriğine uygun olarak hazırlanan 5 adet açık uçlu sorudan oluşan yarı yapılandırılmış görüşme formu aracılı̆̆ıyla X ilinde görev yapan 20 öğretmenden yüz yüze yapılan görüşmelerle elde edilmiştir. Araştırmanın nicel bulguları öğretmenlerin, okul yöneticilerinin iletişim becerilerini yüksek düzeyde olumlu algıladıklarını; nitel bulgular ise öğretmenlerin, okul yöneticilerinin iletişim becerilerini genel olarak yeterli bulmadıklarını göstermektedir. Bu bağlamda nitel bulguların nicel bulguları desteklemediği buna bağlı olarak okul yöneticilerinin iletişim becerilerinde sorunlar olduğu söylenebilir. Nitel ve nicel bulgular arasındaki farklılıklar ise nicel ve nitel araştırma yöntemlerinin farklı paradigmalara sahip olmasına bağlanabilir.

Anahtar kelimeler: iletişim, okul yöneticilerinin iletişim becerileri, branş öğretmenleri

\section{Giriş}

İletişim, tüm varlıklar için çok önemli bir faaliyettir (Şen, 2006) ve toplumsal yaşam iletişim üzerine kuruludur. Çünkü iletişim aracilığıyla insan diğerlerini anlamak ve kendini anlatmak durumundadır (Doğuş, 2011). İletişim kavramı, pek çok kişi tarafından çok farklı yönleri ve boyutlarıyla önemsenip ele alındığ 1 için çok farklı şekillerde yorumlanmıştır (Ergin, 2012). Sayers, Bingaman, Graham ve Wheeler (1993)'e göre iletişim, çeşitli amaçlara varmak için sözcüklerin ve diğer simgelerin kullanılmasıdır. Başaran (2000) ise, iletişimin farklı bir yönüne vurgu yapmış ve genel anlamıyla iletişimi, "insanların birbirlerini yanıtlama çabalarını içeren bir etkileşim süreci”" şeklinde tanımlamıştır. Nitekim Cüceloğlu (1997) da iletişimin bu yönüne vurgu yapmış ve iletişimi iki birim arasında gerçekleşen birbirleriyle ilişkili mesaj alışverişi şeklinde ifade etmiştir. Benzer şekilde Şişman (2003), Ergin (1998), Gürgen (1997), Tutar ve Yılmaz (2008) iletişimin bilgi aktarımı ve paylaşımı yönüne vurgu yapmış ve iletişimi insanların duygularını, düşüncelerini ve bilgilerini tek yönlü veya çift yönlü; yazılı, sözlü ve sözsüz olarak aktarması ve paylaşması süreci şeklinde belirtmişlerdir.

İnsan, iletişim içinde olan sosyal bir varlıktır (Dökmen, 2005) ve iletişim, insan yaşamındaki bütün faaliyetlerle ilgilidir. Bundan dolayı da iletişim, yaşamın her yerinde ve her zaman vardır (Zıllığlu, 2003). İnsanlar, iletişim vasıtasıyla duygularını, düşüncelerini ve fikirlerini paylaşırlar (Köleşoğlu, 2009). Zaten iletişimin temelinde, bireyin diğer bireylerle bağlantı kurma yoluyla kendisini anlatması vardır (Adair, 2004). İnsanlar arasında etkileşimin artması insanların birbirlerine karşı olan duygularını da

\footnotetext{
*Araştırmanın nicel verileri Osman Koçak'ın yüksek lisans tezinden alınmıştır.

** Corresponding Author: Yrd. Doç. Dr., Cumhuriyet Üniversitesi, Sivas, Türkiye, snr312@gmail.com

**** Dr., Kara Harp Okulu, Ankara, Türkiye, scetin93@gmail.com

**** Öğretmen, Milli Eğitim Bakanlığı, Sivas, Türkiye, kocak.2012@hotmail.com
} 
olumlu yönde etkilemektedir (Schein, 1976). Bu tanımlamalar ve açıklamalar doğrultusunda değerlendirildiğinde iletişimin birey, örgüt ve toplum açısından vazgeçilmez bir araç olduğu anlaşılmaktadır.

Örgütsel anlamda dünyadaki gelişim ve yenilikleri okuyup anlayabilmek kaliteli personel ve örgütsel iletişim becerilerini gerekli kılmaktadır (Demir, 2005). Bu bağlamda örgütün işleyişini sağlamak, örgütün amaçlarını gerçekleştirebilmek ve örgüt içerisindeki çalışanlar arasında yüksek dayanışma ortamı oluşturmak için etkili bir örgütsel iletişim şarttır (Aydın, 2010). Eğitim örgütleri ise farklı motivasyona, programa, yaşam biçimlerine, iletişim yapılarına sahip farklı insanlardan oluşmaktadır (Korkmaz, 1995). Bir eğitim örgütü olan okullarda, hedeflenen amaçlara ulaşılmasında, verimin arttırılmasında en büyük etkenlerden biri de, insanlarla etkili iletişim kurabilen, iletişim becerilerine sahip yöneticilerin olmasıdır (Durukan, 2003).

Okul yöneticisi okulun amaçlarını yerine getirebilmek için okuldaki tüm işgörenleri örgütleyen, emirler veren, çalışmaları yönlendirip koordine eden ve denetleyen kişidir. Okul yöneticisi, Milli Eğitim Bakanlığı'nın eğitim politikaları ve amaçları doğrultusunda okulunu en iyi şekilde yönetmeyi amaçlar (Gürsel, 1997). Bu bağlamda bir okulda iletişim sürecini başlatan, iletişimin yapısını ve niteliğini belirleyen en önemli öğe okul müdürüdür (Celep, 2000). Okul örgütünün insan kaynakları yöneticisi konumunda olan okul müdürü, aynı zamanda bir iletişim lideridir. İletişimin olmadığı bir örgüt olamaz. Yine iletişim olmadan okul örgütünde ortak bir amacın olması ve bu amacın gerçekleştirilebilmesi ve okul örgütünün insan kaynaklarının eşgüdümleşmesi imkânsızdır (Karsl1, 2006). Bu sebeple bir eğitim örgütü olan okullarda etkili bir iletişim ağının olması adeta bir zorunluluktur. Bursalıoğlu (2010), bir eğitim örgütü olan okuldaki demokratik yönetim anlayışı ile iletişim arasında doğru bir orantı olduğunu ifade etmektedir. Bir okulda hedeflenen amaçlara etkili bir şekilde ulaşılabilmesi ve okulda demokratik bir iklimin oluşması için yönetici-öğretmen, öğretmen-yönetici iletişimi yani çift yönlü iletişim gereklidir (Celep, 2000). Okuldaki etkili iletişimin niteliği, okul yöneticisinin öğretmenler ve öğrencilerle kurduğu güçlü iletişim alanının büyüklüğüne işaret eder (Marzano, Waters, \& Mcnulty, 2005). Bu kapsamda okulun etkili ve verimli çalışabilmesi konusunda öğretmenler ve yöneticiler arasında kurulan iletişimin riskten uzak ve şeffaf olması gerekir (Rafferty, 2003) çünkü lider özelliklerine sahip okul yöneticilerinin aynı zamanda iletişim yeteneklerinin de üst düzeyde olması beklenir (Neves ve Lens, 2005).

İlgili alan yazın incelendiğinde eğitim kurumlarında okul yöneticilerinin iletişim becerilerine ilişkin çalışmalara rastlanmaktadır (Argon \& Zafer, 2009; Ärlestig, 2007; Aslanargun \& Bozkurt, 2012; Aydoğan \& Kaşkaya, 2010; Doğan, Uğurlu, Y1ldırım, \& Karabulut, 2014; Durgun, 2011; Halawah, 2005; Myran, Sanzo, \& Clayton, 2011; Özan, 2006; Rowicki, 1999; Şimşek \&Altınkurt, 2009). Bu çalışmalarda okul yöneticilerinin iletişim becerileri genel olarak nicel yöntemlerle incelenmiştir. Bu bağlamda alan yazında ortaokullarda görev yapan branş öğretmenlerinin okul yöneticilerinin iletişim becerilerine ilişkin algılarının hem nitel hem de nicel yöntem ile birlikte değerlendirildiği karma yönteme dayalı bir çalışmaya rastlanmamıştır. Araştırmaya 
getirilen bu farklı bakış açısı ile okul yöneticilerinin iletişim becerileri hem "Okul müdürlerinin İletişim Becerileri Ölçeği” aracılığıyla öğretmen algıları hem de açık uçlu sorularla öğretmen görüsslerine dayalı olarak değerlendirilmiş, nicel ve nitel bulgular karşılaştırılarak konu hakkında daha güvenilir sonuçlara ulaşılmıştır. Araştırma bu bakımdan okul yöneticilerinin iletişim becerileri konusunda yapılan diğer araştırmalardan farklılaşmakta alan yazına yeni bir bakış açısı kazandırmasıyla önem arz etmektedir. $\mathrm{Bu}$ kapsamda araştırmanın amacı okul yöneticilerinin iletişim becerilerinin ortaokullarda görev yapan branş öğretmenlerinin algılarına ve görüşlerine göre değerlendirilmesidir.

\section{Yöntem}

\section{Araştırma Modeli}

Araştırma nicel ve nitel yöntemlerin birlikte kullanıldığı açıklayıcı (explanatory) desende yapılandırılmıştır. Açıklayıcı desende önce nicel veriler toplanır, sonra bu verileri yorumlamak için nitel araştırmaya gidilir (Fraenkel \& Wallen, 2006; Akt., Sönmez \& Ceylanpınar, 2011). İki araştırma yönteminin birlikte kullanılmasıyla konu ile ilgili daha kapsamlı ve derinlemesine bilgi edinilmesi, araştırma sonucunda daha güvenilir ve sağlıklı çıkarımlarda bulunulması amaçlanmaktadır.

Nicel araştırma modeli. Araştırmanın nicel bölümü tarama modeline göre desenlenmiştir. Karasar'a (2011) göre tarama modeli, geçmişte ya da halen var olan bir durumu var olduğu şekliyle betimlemeyi amaçlayan araştırma yaklaşımıdır. Araştırmaya konu olan olay, birey ya da nesne, kendi koşulları içinde ve olduğu gibi tanımlanmaya çalışılır. Onları, herhangi bir şekilde değiştirme, etkileme çabası gösterilmez. Bu kapsamda araştırmada ortaokullarda görev yapan branş öğretmenlerinin algılarına göre okul yöneticilerinin sosyal iletişim becerileri incelenmiştir.

Nitel araştırma modeli. Çalışmanın nitel bölümünde durum deseni kullanılmıştır. Nitel durum çalışmasının amacı belirli bir duruma ilişkin sonuçlar ortaya koymak iken en temel özelliği bir ya da birkaç durumun katılımcı gözlemleri, derinlemesine görüşmeler yoluyla doküman toplama ile elde edilen ve analiz edilen verilerin derinliğine ve boylamsal olarak incelenmesini içerir (Yıldırım ve Şimşek, 2011). Bu kapsamda katılımcıların, okul yöneticilerinin sosyal iletişim becerilerine ilişkin görüşleri açık uçlu sorular aracılığıyla irdelenmiştir.

\section{Çalışma Grubu}

Nicel yöntemde kullanılan çalışma grubu. Araştırmanın nicel bölümünde evreni 2012-2013 eğitim-öğretim yılında X il merkezinde bulunan ortaokullarda görev yapan Türkçe, Matematik, Fen ve Teknoloji, Sosyal Bilgiler ve İngilizce branşlarında toplam 531 öğretmen oluşturmaktadır. Araştırma sonucundan daha sağlıklı sonuçlar elde edebilmek amacıyla öğretmen sayısı birbirine en yakın olan söz konusu beş branş araştırmanın evreni olarak belirlenmiştir. 
Araştırmanın örneklemi ise, olasılık temelli örnekleme yöntemlerinden olan seçkisiz örnekleme yöntemiyle belirlenmiştir. Seçkisiz örnekleme yöntemi, örneklemin istatistiksel hesaplamalarla evreni temsil edebilecek büyüklüğe sahip ve tamamen rastgele seçilmesidir (Şimşek ve Yıldırım, 2006). Araştırma örnekleminin hesaplanmasında aşağıdaki formül kullanılmıştır (Yazıcıŏglu ve Erdoğan, 2004).

$$
\begin{aligned}
& n=\frac{N \cdot t^{2} \cdot p \cdot q}{(N-1) \cdot d^{2}+t^{2} \cdot p \cdot q} \Rightarrow n=\frac{531 \cdot(1.96)^{2} \cdot(0.5) \cdot(0.5)}{530 \cdot(0.05)+(1.96)^{2} \cdot(0.5) \cdot(05)} \\
& n=224 \text { olarak hesaplanmıştır. }
\end{aligned}
$$

Yapılan hesaplamalara göre araştırmanın örneklemini X Merkez ilçedeki ortaokullarda Türkçe, Matematik, Fen ve Teknoloji, Sosyal Bilgiler ve İngilizce branşlarında görev yapan 224 branş öğretmeni oluşturmaktadır. Araştırmanın uygulama kısmında kullanılan istatistiksel metotların varsayımlarından olan normallik varsayımının sağlanması için normal dağılımın dışına çıkan uç değerlere sahip 13 öğretmene ait veriler çalışmadan çıkarılmış ve söz konusu istatistiksel analizlerde 211 öğretmene ait veriler kullanılmıştır. Araştırmanın örneklemini oluşturan öğretmenlere ilişkin kişisel bilgilere Tablo 1'de yer verilmiştir.

Tablo 1

Araştırmaya katılan öğretmenlere iliş̧kin kişisel bilgiler

\begin{tabular}{llcc}
\hline Değişkenler & Kategoriler & $f$ & $\%$ \\
\hline \multirow{2}{*}{ Cinsiyet } & Erkek & 106 & 50.2 \\
& Kadın & 105 & 49.8 \\
\hline \multirow{3}{*}{ Branş } & Mürķe & 57 & 27.0 \\
& Matematik & 45 & 21.3 \\
& Fen ve Teknoloji & 39 & 18.5 \\
& Sosyal Bilgiler & 30 & 14.2 \\
& İngilizce & 40 & 19.0 \\
\hline \multirow{3}{*}{ Mesleki Kıdem } & 1-5 Yil & 24 & 11.4 \\
& 6-10 Y1l & 86 & 40.8 \\
& 11-15 Yil & 61 & 28.9 \\
\hline Toplam & 16 Yil ve Üstü & 40 & 19.0 \\
\hline
\end{tabular}

Tablo 1'de görüldüğü üzere çalışmaya katılan öğretmenler, cinsiyete göre değerlendirildiğinde \%50.2'sinin erkek, \%49.8'inin kadın olduğu; branşlarına göre değerlendirildiğinde \%27'sinin Türkçe, \%21.3'ünün Matematik, \%18.5'inin Fen ve Teknoloji, \% 14.2'sinin Sosyal Bilgiler ve \%19.0'unun da İngilizce branşlarında olduğu; mesleki kıdeme göre değerlendirildiğinde \%11.4'ünün 1-5 y1l, \%40.8'inin 6-10 
y11, \%28.9’unun 11-15 y1l ve \%19'unun da 16 y1l ve üstü kıdeme sahip olduğu görülmüştür.

Nitel yöntemde kullanılan çalışma grubu. Araştırmanın nitel bölümünde amaçlı örnekleme yöntemlerinden maksimum çeşitlilik örnekleme yöntemi kullanılmıştır. Maksimum çeşitlilik örneklemesi; göreli olarak küçük bir örneklem oluşturarak bu örneklemde çalışılan probleme taraf olabilecek bireylerin çeşitliliğini maksimum derecede yansıtmaktır (Yıldırım \& Şimşek, 2011). Bu bağlamda araştırmada, okul yöneticilerinin iletişim becerilerine taraf olan öğretmenler örnekleme alınmıştır. Buna göre örnekleme alınacak katılımcılar belirlenirken branş, cinsiyet ve mesleki kıdem kriterleri dikkate alınmıştır. Branş dağılımına göre 5 branştan, her bir branştan 4 öğretmen olmak üzere; cinsiyet dağılımına göre 10 erkek 10 kadın öğretmen olmak üzere; mesleki kıdem dağılımına göre 6's1 1-7 yıl kıdeme sahip, 7'si 8-15 y1l kıdeme sahip ve 5'i 15 ve üstü kıdeme sahip olmak üzere toplam 20 öğretmen örnekleme alınmıştır. Aynı zamanda katılımcılar belirlenirken görüşme yapmayı kabul etme ve katılmaya istekli olma durumu da göz önünde bulundurulmuştur.

\section{Veri Toplama Araçları}

Nicel veri toplama araçları. Araştırmanın nicel bölümünde araştırmada veri toplama aracı olarak kullanılan anketin ilk bölümünde ortaokullarda görev yapan branş öğretmenlerinin demografik özelliklerini incelemek amaciyla Kişisel Bilgi Formu; ikinci bölümünde, Şimşek (2003) tarafından geliştirilen “Okul Müdürlerinin İletişim Becerileri” adlı ölçek kullanılmıştır.

Şimşek'in (2003) geliştirdiği ölçek 36 madde ve 17 boyuttan oluşmaktadır. Ancak, söz konusu ölçekte bazı boyutlar sadece bir maddeden oluşmaktadır. Bu bağlamda ilgili literatürde yer alan ve bir faktör en az iki maddeden oluşmalıdır (Büyüköztürk, 2010; Durmuş, Yurtkoru \& Çinko, 2011) şeklinde oluşan genel görüşe dayanılarak ölçeğin yeniden yapılandırılması gerekliliği ortaya çıkmıştır. Bu doğrultuda ölçeği geliştiren araştırmacının izni alınmış ve ölçek Sivas il merkezindeki ortaokullarda görev yapan ve uygun örnekleme yöntemiyle seçilen 150 branş öğretmenine yeniden uygulanmıştır. Uygulama sonucunda elde edilen verilerin faktör analizi için uygunluğu Kaiser-Meyer-Olkin (KMO) katsayısı ve Bartlett Sphericity testi ile test edilmiştir. KMO değerinin genellikle .60'dan yüksek çıkması beklenir. Ayrıca Bartlett Sphericity testinin de .05 anlamlılık düzeyine göre anlamlı olması gerekmektedir. Yapılan testler sonucunda Kaiser-Meyer-Olkin $(K M O)=.941$ ve Bartlett Sphericity = 4574.93; p=.000 olarak hesaplanmıştır. $\mathrm{Bu}$ sonuçlar doğrultusunda verilere faktör analizini uygulanmıştır. Faktör analizinde özdeğeri 1 ya da 1 'den daha büyük olan faktörler önemli faktörler olarak kabul edilmektedir. Alanyazın incelendiğinde faktör örüntüsünün oluşturulmasında maddelerin faktör yüklerinin alt noktası. 30. ile .40 arasında alınabileceği ifade edilmektedir (Büyüköztürk, 2010). Bu araştırmada maddelerin faktör yükü alt kesme noktası .40 kabul edilmiştir. Faktör analizi sonuçlarına göre faktör yük değeri .40 'ın altında olan 10, 26 ve 30’uncu maddeler 
sırasıyla çıkarılmış ve her madde çıkarımından sonra yapılan faktör analizine göre özdeğeri 1' den büyük olan beş boyutlu bir faktör yapısı ortaya çıkmıştır. Bu beş faktör madde içerikleri doğrultusunda adlandırılmıştır. Yapılan faktör analizi sonucunda maddelere ait faktör yük değerleri, faktörlerin açıkladığı varyans ve Cronbach Alpha iç güvenirlik katsayıları Tablo 2'de verilmiştir.

Tablo 2

Okul müdürlerinin iletişim becerileri ölçeği faktör analizi sonuçları

\begin{tabular}{|c|c|c|c|c|}
\hline Faktör $A d \imath$ & Madde No & $\begin{array}{c}\text { Faktör Yük } \\
\text { Değeri }\end{array}$ & $\begin{array}{c}\text { Faktörün } \\
\text { Açıklayıcılı̆̆g (\%) }\end{array}$ & $\begin{array}{l}\text { Güvenirlik Katsayıs } \\
\text { (Cronbach's Alpha) }\end{array}$ \\
\hline \multirow{12}{*}{$\begin{array}{l}\text { Empatik } \\
\text { Düşünme }\end{array}$} & 1 & .590 & \multirow{12}{*}{20.02} & \multirow{12}{*}{.933} \\
\hline & 9 & .627 & & \\
\hline & 15 & .567 & & \\
\hline & 25 & .539 & & \\
\hline & 27 & .655 & & \\
\hline & 28 & .648 & & \\
\hline & 29 & .651 & & \\
\hline & 31 & .528 & & \\
\hline & 33 & .684 & & \\
\hline & 34 & .676 & & \\
\hline & 35 & .528 & & \\
\hline & 36 & .535 & & \\
\hline \multirow{7}{*}{ Bilgi Aktarımı } & 13 & .523 & \multirow{7}{*}{12.39} & \multirow{7}{*}{.887} \\
\hline & 16 & .479 & & \\
\hline & 17 & .733 & & \\
\hline & 18 & .582 & & \\
\hline & 19 & .588 & & \\
\hline & 20 & .646 & & \\
\hline & 32 & .658 & & \\
\hline \multirow{6}{*}{ Önyarg1 } & 2 & .578 & \multirow{6}{*}{11.01} & \multirow{6}{*}{.733} \\
\hline & 3 & .583 & & \\
\hline & 8 & .470 & & \\
\hline & 11 & .632 & & \\
\hline & 12 & .736 & & \\
\hline & 14 & .823 & & \\
\hline \multirow{4}{*}{ Planlama } & 21 & .642 & \multirow{4}{*}{10.58} & \multirow{4}{*}{.837} \\
\hline & 22 & .586 & & \\
\hline & 23 & .711 & & \\
\hline & 24 & .631 & & \\
\hline \multirow{4}{*}{ Olumlu Tutumlar } & 4 & .443 & \multirow{4}{*}{7.35} & \multirow{4}{*}{.816} \\
\hline & 5 & .510 & & \\
\hline & 6 & .596 & & \\
\hline & 7 & .736 & & \\
\hline Açıklan & oplam Var & $=61.35$ & \multicolumn{2}{|c|}{ Kaiser Meyer Olkin $(K M O)=.941$} \\
\hline Bartlett & ricity Test & Kare $=457$ & $4.93 \quad s d=528$ & $=.000$ \\
\hline
\end{tabular}


Tablo 2 incelendiğinde "Empatik Düşünme" faktörü ölçeğe ilişkin toplam varyansın \%20.02'sini, "Bilgi Aktarımı" faktörü \%12.39'unu, "Önyargı" faktörü \%11.01'ini, "Planlama” faktörü \%10.58'ini ve “Olumlu Tutumlar” faktörü de \%7.35'ini açıklamaktadır. Bu beş faktör ise toplam varyansın \%61.35'ini açıklamaktadır. Sosyal bilimlerde açıklanan varyansın \%40 ile \%60 arasında olması ideal kabul edilmektedir (Büyüköztürk, 2010). Faktörlerin iç güvenirliğinin hesaplanmasında iç tutarlılık katsayısına bakılmıştır. Bu değerler "Empatik Düşünme" faktörü için .933, "Bilgi Aktarımı" faktörü için .887, "Önyargı" faktörü için .733, "Planlama” faktörü için 837 ve "Olumlu Tutumlar” faktörü için de .816 olarak hesaplanmıştır. Ölçeğin bütün olarak güvenirlik katsayısı ise .961 olarak hesaplanmıştır. Sosyal bilimlerde bir ölçeğin güvenilir olması için ölçek .70'in üzerinde bir katsayıya sahip olması gerekmektedir (Büyüköztürk, 2010). Bu nedenle ölçeğin güvenilir olduğu söylenebilir.

Nitel veri toplama araçları. Araştırmanın soruları hazırlanırken "Okul Müdürlerinin İletişim Becerileri” ölçeğinin alt boyutları dikkate alınmıştır. Ölçek boyutları kapsamında hazırlanan açık uçlu sorular öncelikle araştırmanın çalışma grubunda olmayan iki öğretmene yöneltilmiş, elde edilen sonuçlara göre soruların açık ve anlaş1lır olduğu görülmüştür. Ayrıca sorular nitel araştırmalar konusunda uzman bir öğretim üyesi tarafından incelemeye tabi tutulmuş ve son olarak bir Türkçe öğretmeni tarafından gözden geçirilmiştir.

Veri toplama sürecinde katılımcılara açık uçlu sorular yöneltilerek araştırma sürecinde beklenmeyen veya planlanmayan cevapların alınması sağlanmış, böylece konu hakkında daha geniş ve ayrıntılı bilgiye sahip olunmuştur (Büyüköztürk, Çakmak, Akgün ve Demirel 2012). Bu kapsamda araştırmada katılımcılara yöneltilen sorular şunlardır: i) Yöneticinizin iletişim becerilerini genel olarak nasıl değerlendiriyorsunuz? ii) Yöneticinizin empatik düşünme becerilerine ilişkin görüşleriniz nelerdir? (empatik düşünme boyutu) iii) Yöneticinizin bilgi aktarımı becerilerine ilişkin görüşleriniz nelerdir? (bilgi aktarımı boyutu). iv) Yöneticinizin planlama becerilerine ilişkin görüşleriniz nelerdir? (planlama boyutu) v) Yöneticinizin iletişimde önyargılı olmama becerisine ilişkin görüşleriniz nelerdir? (önyargı boyutu). "Olumlu tutumlar” boyutu diğer boyutların içeriğinde değerlendirilerek bu boyut için ayrı bir soru hazırlanmamıştır. Araştırma kapsamında elde edilen sorular 20 katılımcıya yöneltilmiştir. Araştırmaya ilişkin veriler Ocak 2014- Mart 2014 tarihleri arasında belirlenen katılımcılarla yapılan konu odaklı görüşme yöntemiyle toplanmıştır. Konu odaklı görüşmeler kişilerin yaşamlarından ziyade bir program, konu ya da süreç üzerine odaklanmış görüşmelerdir. Görüşmeler hakkında katılımcılara bilgi verilmiş daha sonra katılımcılardan randevu alınmış ve tam randevu saatinde okullara gidilerek sessiz bir ortamda görüşmeler gerçekleştirilmiştir. Görüşmelerde katılımcıların onayı ile ses kayıt cihazı kullanılarak 420 dakikalık ses kaydı elde edilmiştir. 


\section{Verilerin Analizi}

Nicel verilerin analizi. Öğretmenlerin demografik özelliklerine ilişkin yapılan analizlerde frekans ve yüzde değerlerine; okul müdürlerinin iletişim becerilerine ilişkin olarak, seçeneklere göre kodlanan puan aralığı dağılımı ve bazı değişkenlere göre genel dağılım hesaplanırken, aritmetik ortalama ve standart sapma değerlerine yer verilmiştir. Veriler SPSS 18. paket programında analiz edilmiştir.

Nitel verilerin analizi. Araştırma sürecinde katılımcılarla yüz yüze gerçekleştirilen tüm görüşmeler, ses kayıt cihazıyla, katılımcıların onayı alınarak kaydedilmiştir. $\mathrm{Bu}$ kapsamda katılımcılar ile 420 dakikalık görüşme yapılmıştır. Görüşmelerden sonra kaydedilen veriler ham veri olarak Microsoft Word yazı işleme programıyla metne dönüştürülmüştür. Veriler kodlanmadan önce iki araştırmacı tarafından verilerin dökümü olan transkriptler satır satır okunmuştur. Görüşme verilerinin yorumlanması sürecinde betimsel analiz, içerik analizi ve sürekli karşılaştırma tekniği kullanılmıştır. İçerik analizi, yazılı ve sözlü materyallerin sistemli bir analizidir. İçerik analizi, bir söylemi anlamada ve yorumlamada, öznel etkenlerden kurtularak toplanan verileri açıklayabilecek kavramlara ve ilişkilere ulaşma amacı taşımaktadır (Bilgin, 2006; Yıldırım \& Şimşek, 2011). Betimsel analizde toplanan veriler üzerinde hiçbir işlem yapmadan onların okuyucuya olduğu gibi sunulması savunulur. Burada araştırmacının yorumlayarak verileri olduğundan farklı bir biçimde göstermesi engellenmektedir. Verilerin olduğu gibi, açık, anlaşılır şekilde sunulması tarafsızlığın sağlanması için de gerekli olabilir (Sönmez \& Alacapınar, 2011). Sürekli karşılaştırma analizinde ise veriler önceden düzenlenmiş kategorilere göre analiz edilmez. Önce veriler elde edilir, sonra onlar kategorize edilir. Bu araştırma yönteminde verilerin sürekli karşılaştırılması söz konusudur. Benzerlik, benzer anlam içeren özellikler kalmadığı zaman yeni kategoriler oluşturulmalı ve veriler o kategorilere yerleştirilmelidir (Strauss \& Corbin, 1990; Strauss \& Corbin, 1998: Akt. Sönmez \& Ceylanpınar, 2011). Bu amaçla veriler dört aşamada analiz edilmiştir: (1) verilerin kodlanması, (2) temaların bulunması, (3) kodların ve temaların düzenlenmesi, (4) bulguların tanımlanması ve yorumlanması. Tekrardan kaçınmak açısından aynı içerikli cevaplara tabloda bir defalığına yer verilmiştir. Araştırmacı tarafından elde edilen verilerin içeriği irdelendiğinde elde edilen sonuçların "yeterli, kısmen yeterli, yetersiz" olmak üzere üç kategoride ele alınmasının uygun olduğu görülmüştür. Tavşancıl ve Aslan'a göre (2001) kategorileştirme türlerinden değerlendirici kategoriler iyi-kötü, doğru-haksız vb. tarzda sınıflandırılabilir. Araştırmada bu nedenle yeterli, kısmen yeterli ve yetersiz şeklinde değerlendirici kategoriler kullanılmıştır. Katılımcılara (K1, $\mathrm{K} 2, \mathrm{~K} 3 \ldots \ldots \mathrm{K} 20)$ şeklinde rumuzlar verilmiştir.

Nitel araştırmada geçerlik ve güvenirlik. Nitel araştırma yaklaşımının benimsendiği bu araştırmada geçerlik ve güvenirlik kavramları yerine inandırıcılık, aktarılabilirlik, tutarlılık ve teyit edilebilirlik kavramlarının kullanılması daha doğru bir yaklaşım olacaktır. Geçerlik ve güvenirlik kavramları nicel araştırmalara özgü kavramlar niteliğinde olup, nitel araştırmaların temel ilkeleri ve temel paradigması ile 
çelişmektedir (Mills, 2003). Bu kapsamda araştırmada inandırıcılığı sağlamak için öncelikle araştırmanın uygulama sürecinde tüm görüşmeler ses kayıt cihazıyla kayıt altına alınmıştır. Araştırmacı, araştırmanın tüm aşamalarında mümkün olduğunca objektif olmaya dikkat etmiştir. Aktarılabilirlik konusunda araştırmacıların okuyuculara, uygulama ve içerikteki benzerliklere karar vermesi için yeterli detayları vermesi gerekmektedir. Bu nedenle çalışmanın yöntem bölümünde; araştırmanın yapıldı̆̆ 1 yer, zaman ve içerik ile ilgili açıklayıcı bir şekilde bilgi verilmiştir. Araştırmanın tutarlılığını artırmak için çalışmada elde edilen bulguların tamamı yorum ve genelleme yapılmadan doğrudan okuyucuya sunulmuştur. Araştırmanın teyit edilebilirliğini sağlamak için verilerin nasıl toplandığı, verilerin nasıl kaydedildiği ayrıntılı bir şekilde anlatılmıştır. Ayrıca araştırma sürecinde elde edilen tüm veriler, araştırmacının kendisi dışında, başka bir araştırmacı tarafından değerlendirip, ayrı ayrı kodlanmış ve tüm kodlamalar arasında genel anlamda görüş birliği sağlanmıştır. İki araştırmacının birbirinden bağımsız olarak kullandıkları kodların tutarlığı "Görüş Birliği” ya da "Görüş Ayrılığı" şeklinde işaretlemeler yapılarak belirlenmiştir. Araştırmada tüm kodlamalar güvenilirlik hesaplaması için; Miles ve Huberman'ın (1994) önerdiği güvenirlik formülü [Güvenirlik= Görüş Birliği / (Görüş Birliği + Görüş Ayrılı̆̆ı)] kullanılmıştır. Her bir sorun için yapılan güvenirlik hesaplamasında \% 90 ile $\% 92$ arasında bir sonuca ulaşılmıştır.

\section{Bulgular}

\section{Nicel Bölümden Elde Edilen Bulgular ve Yorumlar}

$\mathrm{Bu}$ bölümde, ilk olarak öğretmenlerin motivasyon algılarına ilişkin olarak aritmetik ortalama, standart sapma ve seçeneklere göre kodlanan puan aralığı (SKPA) değerlerine yer verilmiştir. Daha sonra öğretmenlerin, okul yöneticilerinin iletişim becerileri konusundaki algıları toplam puan üzerinden kıdem, branş ve cinsiyet değişkenlerine göre incelenmiş; ancak araştırma deseni kapsamında nicel ve nitel bulguların daha sağlıklı bir şekilde karşılaştırılabilmelerini sağlamak için ilgili demografik değişkenler arasındaki farklılıklara yer verilmemiştir.

Öğretmenlerin, okul yöneticilerinin iletişim becerilerine ilişkin algılarının genel dağılımı Tablo 3'te sunulmuştur. 
Tablo 3

Öğretmen görüşlerine göre okul yöneticilerinin iletişim becerilerine ilişkin genel dağılım

\begin{tabular}{lcccl}
\hline & $n$ & $\overline{\mathrm{X}}$ & SS & Seçeneklere Göre Kodlanan Puan Aralı̆̆ $($ SKPA) \\
\hline Empatik düşünme & 211 & 4.31 & 0.59 & Tamamen Katılıyorum \\
\hline Bilgi aktarımı & 211 & 4.38 & 0.55 & Tamamen Katılıyorum \\
\hline Önyarg1 & 211 & 4.19 & 0.54 & Katılıyorum \\
\hline Planlama & 211 & 4.17 & 0.65 & Katılıyorum \\
\hline Olumlu tutumlar & 211 & 4.50 & 0.71 & Tamamen Katılıyorum \\
\hline İletişim becerileri (Toplam) & 211 & 4.31 & 0.61 & Tamamen Katılıyorum \\
\hline
\end{tabular}

Tablo 3, okul yöneticilerinin iletişim becerileri ölçeği ve alt boyutlarından alınan puanların seçeneklere göre kodlanan puan aralığı (SKPA) dikkate alınarak değerlendirildiğinde, öğretmenlerin empatik düşünme boyutunu "tamamen katıllyorum" düzeyinde; bilgi aktarımı boyutunu "tamamen katılıyorum" düzeyinde; önyarg1 boyutunu "kat1lyorum" düzeyinde; planlama boyutunu "katılıyorum" düzeyinde; olumlu tutumlar boyutunu "tamamen katıliyorum" düzeyinde; okul yöneticilerinin iletişim becerileri ölçeğini toplamda ise "tamamen katılıyorum" düzeyinde algıladıkları görülmektedir. $\mathrm{Bu}$ bağlamda değerlendirildiğinde öğretmenlerin okul yöneticilerinin iletişim becerilerine ilişkin alg1 puanları yüksek düzeyden düşük düzeye doğru olumlu tutumlar, bilgi aktarımı, empatik düşünme ve planlama boyutları şeklinde sıralanmıştır. $\mathrm{Bu}$ durum ise öğretmelerin, okul yöneticilerinin iletişim becerilerini empatik düşünme, bilgi aktarımı ve olumlu tutumlar boyutlarında yüksek düzeyde yeterli; önyargı ve planlama boyutunda ise yeterli düzeyde algıladıkları şeklinde açıklanabilir. Okul yöneticilerinin iletişim becerileri ölçeğinden alınan toplam puanın "tamamen katılıyorum" düzeyinde olması ise öğretmenlerin, okul yöneticilerinin iletişim becerilerini toplamda yüksek düzeyde yeterli algıladıklarını göstermektedir.

Öğretmenlerin kıdem, branş ve cinsiyet değişkenlerine göre okul yöneticilerinin iletişim becerilerine ilişkin algılarının dağılımı Tablo 4'de sunulmuştur. 
Tablo 4

Bazl değişkenlere göre okul yöneticilerinin iletişim becerilerine ilişkin ögretmen algılarının puanlar ortalaması ve standart sapma değerleri

\begin{tabular}{|c|c|c|c|c|}
\hline & & $n$ & $\bar{x}$ & ss \\
\hline \multirow{4}{*}{ Kıdem } & 1 ile 5 & 24 & 4.40 & 0.46 \\
\hline & 6 ile 10 & 86 & 4.24 & 0.57 \\
\hline & 11 ile 15 & 61 & 4.27 & 0.64 \\
\hline & 16 ve üstü & 40 & 4.22 & 0.60 \\
\hline \multirow{5}{*}{ Branş } & Türkçe & 57 & 4.35 & 0.55 \\
\hline & Matematik & 45 & 4.32 & 0.59 \\
\hline & Fen ve Teknoloji & 39 & 4.30 & 0.62 \\
\hline & Sosyal Bilgiler & 30 & 4.21 & 0.61 \\
\hline & İngilizce & 40 & 4.33 & 0.55 \\
\hline \multirow{2}{*}{ Cinsiyet } & Kadın & 105 & 4.32 & 0.60 \\
\hline & Erkek & 106 & 4.29 & 0.63 \\
\hline
\end{tabular}

Tablo 4`e göre öğretmenlerin, okul yöneticilerinin iletişim becerilerine ilişkin algılarının ortalamaları kıdem, branş ve cinsiyet değişkenlerine göre $(\overline{\mathrm{x}}=4.21)$ ile $(\overline{\mathrm{x}}=$ 4.40) aralığında değişmektedir. Seçeneklere göre kodlanan puan aralığına (SKPA) göre öğretmenlerin, ilgili değişkenlerin tümünde, okul yöneticilerinin iletişim becerilerine ilişkin algıları " tamamen katılıyorum” düzeyindedir. En yüksek ortalama $(\bar{x}=4.40)$ ile kıdem değişkeninin "1-5 yıl” aralığında iken en düşük ortalama $(\bar{x}=4.21)$ ile branş değişkeninin "sosyal bilgiler” branşında yer almaktadır. Öğretmenlerin okul yöneticilerinin iletişim becerilerine ilişkin algılarının tüm değişkenlerde "tamamen katılıyorum" düzeyinde olması, ortaokullarda görev yapan branş öğretmenlerinin ilgili değişkenlerde benzer algı puanlarına sahip olduklarını göstermektedir.

\section{Nitel Bölümden Elde Edilen Bulgular ve Yorumlar}

Araştırmanın nitel bölümünde öğretmenlerin görüşlerine başvurulmuştur. $\mathrm{Bu}$ kapsam da oluşturulan sorulardan elde edilen görüşler doğrultusunda okul yöneticilerinin iletişim becerilerine ilişkin öğretmen görüşleri, okul yöneticilerinin iletişimde empatik düşünme becerilerine ilişkin öğretmen görüşleri, okul yöneticilerinin iletişimde bilgi aktarımı becerilerine ilişkin öğretmen görüşleri, okul yöneticilerinin iletişimde önyargılı olmama davranışına ilişkin öğretmen görüşleri, okul yöneticilerinin iletişimde planlı davranma becerilerine ilişkin öğretmen görüşler olmak üzere 5 tema oluşturulmuş ve konu bu 5 tema altında incelenmiştir. 
Okul yöneticilerinin iletişim becerilerine ilişkin öğretmen görüşleri. Tablo 5’te okul yöneticilerinin iletişim becerilerine ilişkin öğretmen görüşlerinin dağılımı sunulmuştur.

\section{Tablo 5}

Okul yöneticilerinin iletişim becerilerine ilişkin öğretmen görüşleri

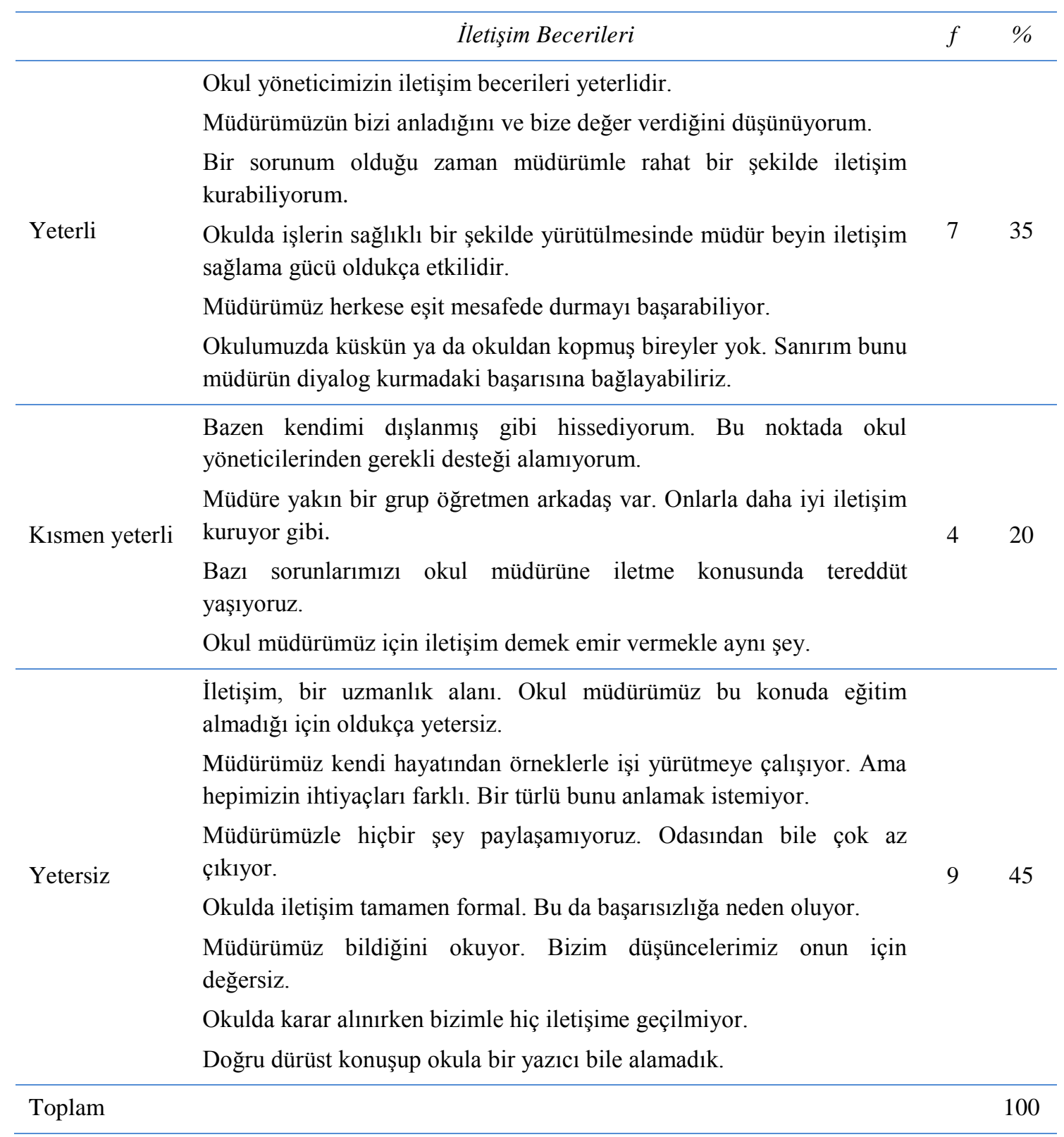

Tablo 5'e göre öğretmenler, okul yöneticilerinin iletişim becerilerine ilişkin olarak \% 35 oranında yeterli $(f=7), \% 20$ oranında kısmen yeterli ( $f=4)$ ve $\% 45$ oranında yetersiz ( $\mathrm{f}=9)$ şeklinde görüş bildirmişlerdir. Verilen cevaplar incelendiğinde: okul yöneticilerinin iletişim becerilerinin yeterli düzeyde olduğu yönünde görüş bildiren öğretmenler, okul yöneticisinin öğretmenlere değer verdiği, rahat iletişim kurabildiği, herkese eşit mesafede durduğu, iletişim anlamında güçlü olduğu ve okulda küskün 
bireyler olmadığg konuları üzerinde; kısmen yeterli yönünde görüş bildiren öğretmenler, yöneticinin kendisine yakın bireylerle daha çok ilgilendiği, iletişimi emir vermek gibi algıladığı, sorunların müdüre iletilmesinde tereddüt yaşandığ1 ve okulda bazen dışlanmışlık hissi oluştuğu konuları üzerinde; yetersiz yönünde görüş bildiren öğretmenler ise okul yöneticisinin iletişim konusunda eğitim almadığ 1 , daha çok tecrübe ile hareket ettiği, farklı ihtiyaçlara duyarsız kaldığ düşüncelere değer vermediği, karar alınırken personele danışmadığ 1 konuları üzerinde durmuşlardır. Elde edilen bulgulara dayanılarak öğretmenlerin, okul yöneticilerinin iletişim beceri düzeylerini genel olarak yeterli bulmadıkları söylenebilir.

Okul yöneticilerinin iletişim becerilerinin yeterli olduğu yönünde görüş bildiren K 10 rumuzlu kat1lımc1 "bu anlamda okulda rahat bir ortam var. Müdür bey her türlü ihtiyacımızla ilgileniyor ve bize değer verdiğini her firsatta dile getiriyor. Iletişim becerileri yüksek bir müdürle çalışmak bizi okula bă̆llyor" ifadelerini kullanırken bu konuda okul müdürlerinin kısmen yeterli olduklarını düşünen K 9 rumuzlu katılımcı "müdürümüzün să̆ solu belli olmuyor. Bir bakmışsınız çok ılımlı ve sevecen bir dil kullanıyor. Bir bakmışsınız otoriter ve soğuk bir dil kullanıyor. Tam olarak iletişim dilini kestirmek zor. Bu durum bizi olumsuz etkiliyor” söyleminde bulunmuş, bu konuda okul müdürünün yetersiz olduğunu düşünen $\mathrm{K} 9$ rumuzlu katılımc1 ise "müdürümüz hala 1980'li yılların dilini kullanıyor. Bizim jenerasyonu anlamakta ve bizimle iletişim kurmakta güçlük çekiyor. Bu nedenle taleplerimiz ona anlamsız geliyor" şeklinde düşüncelerini dile getirmiştir.

Okul yöneticilerinin iletişimde empatik düşünme becerilerine ilişkin öğretmen görüssleri. Tablo 6'da okul yöneticilerinin iletişimde empatik düşünme becerilerine ilişkin öğretmen görüşlerinin dağılımı sunulmuştur.

Tablo 6'ya göre öğretmenler, okul yöneticilerinin empatik düşünme becerilerine ilişkin olarak \%30 oranında yeterli $(f=6), \% 20$ oranında kısmen yeterli $(f=4)$ ve \%50 oranında yetersiz ( $\mathrm{f}=10$ ) şeklinde görüş bildirmişlerdir. Verilen cevaplar incelendiğinde: Okul yöneticilerinin empatik düşünme becerilerinin yeterli düzeyde olduğu yönünde görüş bildiren öğretmenler, okul yöneticisinin empati becerisi sayesinde okulda huzur ortamı olduğu, okuldan tayin istenilmediği, ihtiyaçların karşılandığı, okul başarısının arttığı ve kişisel sıkıntıların giderildiği konuları üzerinde; kısmen yeterli yönünde görüş bildiren öğretmenler, yöneticinin zaman zaman kendilerini anlamakta güçlük çektiği, yöneticilerin değişkenlik gösterdiği ve okulda bazen işlerin karmaşık bir hale geldiği konuları üzerinde; yetersiz yönünde görüş bildiren öğretmenler ise okul yöneticisinin empatik davranma becerisini öğrenemediği için yönetimden herhangi bir şey talep edilemediği, okulda performansın düştüğü, kişisel isteklerin kaytarma ve tembellik olarak algılandığı ve okuldan kopmalar olduğu konuları üzerinde durmuşlardır. Elde edilen bulgulara dayanılarak öğretmenlerin, okul yöneticilerinin empatik düşünme beceri düzeylerini genel olarak yeterli bulmadıkları söylenebilir. 
Tablo 6

Okul yöneticilerinin iletişimde empatik düşünme becerilerine ilişkin ögrretmen görüşleri

Empatik Düşünme $\quad f \quad \%$

Okul yöneticilerimiz empati konusunda yeterlidir.

Empatik davranabildikleri için kendimi huzurlu hissediyorum.

Başkalarının halinden anlayan yöneticilerimiz var.

Yeterli

Müdürümüz empati yapamasaydı çoktan tayin istemiştim.

Zor zamanlarımızda bizimle birlikte üzülen, yeri geldiğinde bizimle sevinen yönetici kadromuz sayesinde okulun başarısı da artıyor.

Bunaldığım zamanlarda beni rahatlatan bir müdüre sahip olmak çok güzel.

Okulda işler bazen karmaşık hale geliyor. Yöneticilerimiz zaman zaman bizi anlamakta güçlük çeliyor.

Kismen yeterli

İnsanlar çok değişken. Tabi yöneticilerde öyle. Bi bakmışsınız kanka, bi bakmışsınız patron.

Hep benim ihtiyaçlarıma duyarlı ve beni anlayabilen bir müdür istemiştim. Ama olmadı, yani kısmen olmadı. Hakkını yemeyelim.

Empati öğrenilmesi gereken bir beceri. Ama bizim yöneticiler maalesef bunu öğrenememişler.

Empatik düşünmeyen yöneticiler yüzünden okuldan soğudum.

Hasta olmaktan korkuyorum. Çünkü müdürümüz kaytardığımı düşünüyor.

Yetersiz

Bence empati eğitimi almayanları yönetici yapmasınlar. Çok çekiyorum çoook.

Empati kim bizimkiler kim. Onlar ancak kendilerine empatik.

Okulda performansım sürekli düşüyor. Çünkü benim durumumu anlamak istemiyorlar.

Müdürümden bir şey istemek beni korkutuyor. Çünkü benim taleplerim ona anlamsız geliyor.

Okul yöneticilerinin empatik düşünme becerilerinin yeterli olduğu yönünde görüş bildiren K 10 rumuzlu katılımc1 "bence okulda empati en önemli meziyet. Özellikle müdürümüzde empati özelliğinin bulunması bize oldukça rahat bir çalışma ortamı sunuyor" ifadelerini kullanırken bu konuda okul müdürlerinin kısmen yeterli olduklarını düşünen K 9 rumuzlu katılımcı "okul yöneticisi tarafindan empati becerisi yeterince işletilmediğinde okulda işler karışıyor. Bu karmaşanın çözümü ise maalesef ögretmenlerin üzerine kallyor" söyleminde bulunmuş, bu konuda okul müdürünün yetersiz olduğunu düşünen $\mathrm{K} 9$ rumuzlu katılımcı ise "okul yöneticimiz maalesef empati yapamıyor. Her türlü talebimizde ve kişisel ihtiyaçlarımızda bizi hırpalıyor. Bu müdür yüzünden işimden soğumaya başladım” şeklinde düşüncelerini dile getirmiştir. 


\section{Okul yöneticilerinin iletişimde bilgi aktarımı becerilerine ilişkin öğretmen} görüşleri. Tablo 7'de okul yöneticilerinin iletişimde bilgi aktarımı becerilerine ilişkin öğretmen görüşlerinin dağılımı sunulmuştur.

\section{Tablo 7}

Okul yöneticilerinin iletişimde bilgi aktarımı becerilerine ilişkin öğretmen görüşleri

\begin{tabular}{|c|c|c|c|}
\hline & Bilgi Aktarımı & $f$ & $\%$ \\
\hline Yeterli & $\begin{array}{l}\text { Okulda bilgiler yazılı olarak bize ulaşıyor. } \\
\text { Okul yöneticileri bizi ilgilendiren konularda bilgi aktarımı yapıyor. } \\
\text { Okulda yapılan her türlü faaliyetten haberimiz oluyor. } \\
\text { Müdürümüz bize sormadan karar almaz. } \\
\text { Bildiklerini paylaşmaktan zevk duyan bir yönetici kadromuzun olması } \\
\text { işlerin daha sağlıklı yürütülmesinde etkilidir. }\end{array}$ & 9 & 45 \\
\hline Kismen yeterli & $\begin{array}{l}\text { Duyurular geç yapıldığı için bazen işlerim aksıyor. } \\
\text { Ben ilgilenmesem çoğu olaydan haberim olmayacak. } \\
\text { Müdür beyi görürsem sorup öğrenebiliyorum. } \\
\text { Bilgi aktarımı sadece resmi belgelerle sınırlı. }\end{array}$ & 4 & 20 \\
\hline Yetersiz & $\begin{array}{l}\text { Okulda yapılan faaliyetlerle ilgili bilgi sahibi olamıyorum. Tesadüfen } \\
\text { öğreniyorum. } \\
\text { Okulda alınan kararlar konusunda bize hiçbir şey sorulmuyor ve } \\
\text { söylenmiyor. } \\
\text { Yazılı evraklar geliyor ama ben bunu bilgi aktarımı olarak kabul } \\
\text { etmiyorum. Pek çok yazının yönetici tarafından açıklanması gerekiyor. } \\
\text { Bilgi aktarımında yaşanan sorunlardan dolayı az daha işimi } \\
\text { kaybediyordum. } \\
\text { Okulda olup bitenleri ancak dedikodu mekanizmasıyla } \\
\text { öğrenebiliyorum. } \\
\text { Yöneticiler bilgiyi paylaşma konusunda çok ketum. Hep bilen taraf } \\
\text { olmak istiyorlar. }\end{array}$ & 7 & 35 \\
\hline
\end{tabular}

Tablo 7'ye göre öğretmenler, okul yöneticilerinin bilgi aktarımı becerilerine ilişkin olarak \% 45 oranında yeterli $(f=9), \% 20$ oranında kısmen yeterli $(f=4)$ ve \%35 oranında yetersiz $(f=7)$ şeklinde görüş bildirmişlerdir. Verilen cevaplar incelendiğinde: Okul yöneticilerinin bilgi aktarımı becerilerinin yeterli düzeyde olduğu yönünde görüş bildiren öğretmenler, okul yöneticisinin öğretmenleri ilgilendiren her konuda yazılı ve sözlü bilgi aktarımı yaptığı, okulda yapılan her türlü faaliyetten haberdar olunduğu, alınan kararlarda kendilerine danışıldığı ve müdürün bilgi paylaşımından zevk duyduğu konuları üzerinde; kısmen yeterli yönünde görüş bildiren öğretmenler, bilgi aktarımının resmi belgelerle sınırlı olduğu, bazı konulardan haberdar olunmadığı ve bazı işlerin aksadığ1 konuları üzerinde; yetersiz yönünde görüş bildiren öğretmenler ise okulda 
yapılan faaliyetlerle ilgili bilgi sahibi olunmadı̆̆ı, alınan kararlarda öğretmenlere danışılmadığı, yazılı evrakların açıklayıcı olmadığı ve bilgi aktarımından çok dedikodu mekanizmasının olduğu konuları üzerinde durmuşlardır. Elde edilen bulgulara dayanılarak öğretmenlerin, okul yöneticilerinin bilgi aktarımı beceri düzeylerini genel olarak yeterli buldukları söylenebilir.

Okul yöneticilerinin bilgi aktarımı becerilerinin yeterli olduğu yönünde görüş bildiren K 10 rumuzlu katılımcı "okulda her türlü bilgiye rahatlıkla ulaşıyoruz. Yapılacak faaliyetler Bizim bilgimiz dahilinde planlanıyor. Okulda verim her geçen gün artıyor" ifadelerini kullanırken bu konuda okul müdürlerinin kısmen yeterli olduklarını düşünen K 9 rumuzlu katılımcı "kişisel çabamız olmasa okulda yapılan çalışmaların çoğundan haberimiz olmayacak. Bilinmesi en doğal bilgilere bile devlet sırr muamelesi yapılıyor" söyleminde bulunmuş, bu konuda okul müdürünün yetersiz olduğunu düşünen K 9 rumuzlu katılımcı ise "okulda bilgi aktarımı yetersiz. Zamanında ulaşılamayan bilgiler nedeniyle sürekli sorunlar yaşıyoruz. Bize söylenmeyen pek çok şeyi hizmetlilerden ögreniyoruz” şeklinde düşüncelerini dile getirmiştir.

Okul yöneticilerinin iletişimde önyargılı olmama davranışına ilişkin öğretmen görüşleri. Tablo 8'de okul yöneticilerinin iletişimde önyargıll olmama davranışına ilişkin öğretmen görüşlerinin dağılımı sunulmuştur.

Tablo 8'e göre öğretmenler, okul yöneticilerinin önyargılı olmama becerilerine ilişkin olarak \% 40 oranında yeterli $(f=8), \% 25$ oranında kısmen yeterli $(f=5)$ ve \%35 oranında yetersiz $(f=7)$ şeklinde görüş bildirmişlerdir. Verilen cevaplar incelendiğinde: Okul yöneticilerinin önyargılı olmama becerilerinin yeterli düzeyde olduğu yönünde görüş bildiren öğretmenler, okul müdürünün herkese eşit mesafede olduğu, herkesin görev almasını sağladığı ve okulda huzur ortamı olduğu konuları üzerinde; kısmen yeterli yönünde görüş bildiren öğretmenler, okul yöneticisinin bazen önyargılı olduğu, menfaatler söz konusu olduğunda önyargıların oluştuğu ve tam anlamıyla önyargısız bir yönetici bulmanın zor olduğu konuları üzerinde; yetersiz yönünde görüş bildiren öğretmenler ise okul yöneticilerinin sahip olduğu önyargılar nedeniyle, pasif çalışanların olduğu, öğretmenlerin şucu bucu şeklinde fişlendiğii, okul paydaşlarının tümüne karşı önyargılı olunduğu ve başarılı olunsa bile önyargıların değişmediği konuları üzerinde durmuşlardır. Elde edilen bulgulara dayanılarak öğretmenlerin, okul yöneticilerinin önyargılı olmama beceri düzeylerini genel olarak yeterli buldukları söylenebilir. 
Tablo 8

Okul yöneticilerinin iletişimde önyargılı olmama becerilerine ilişkin ögrretmen görüşleri

\begin{tabular}{|c|c|c|c|}
\hline & Önyargllı Olmama & $f$ & $\%$ \\
\hline \multirow{5}{*}{ Yeterli } & Müdürüm önyargıdan uzak bir tavır sergileyebiliyor. & \multirow{5}{*}{8} & \multirow{5}{*}{40} \\
\hline & $\begin{array}{l}\text { Önyargılı bir yönetici olsaydı şu anda hissettiğim huzuru sanırım } \\
\text { bulamazdım. }\end{array}$ & & \\
\hline & $\begin{array}{l}\text { Okul müdürü herkese eşit mesafede durmayı başarabiliyor. Bu nedenle } \\
\text { önyargılı olduğunu söyleyemem. }\end{array}$ & & \\
\hline & $\begin{array}{l}\text { Önyargı insani bir özellik. Okul yöneticimiz her insanda birazda olsa } \\
\text { var olan bu durumu bizlere hiç yansıtmadı. }\end{array}$ & & \\
\hline & $\begin{array}{l}\text { Okulda yapılan bütün faaliyetlerde herkesin görev almasını sağlayan ve } \\
\text { gerektiğinde yeren gerektiğinde ise takdir eden önyargısız bir } \\
\text { yöneticimiz var. }\end{array}$ & & \\
\hline \multirow{3}{*}{ Kısmen yeterli } & Bazen önyargılı olduklarını hissediyorum. & \multirow{3}{*}{5} & \multirow{3}{*}{25} \\
\hline & $\begin{array}{l}\text { Duruma göre değişiyor. Menfaatlerimiz çatıştı̆̆ zaman tüm önyargılar } \\
\text { devreye giriyor sanki. }\end{array}$ & & \\
\hline & $\begin{array}{l}\text { Toplum olarak çok bölünmüşüz bence. Bu nedenle tam anlamıyla } \\
\text { önyargısız ve işini profesyonel yapan bir yönetici bulmak zor. }\end{array}$ & & \\
\hline \multirow{6}{*}{ Yetersiz } & Yöneticiler önyargilı olduğu için pasif bir çalışan oldum. & \multirow{6}{*}{7} & \multirow{6}{*}{35} \\
\hline & $\begin{array}{l}\text { Okula geldiğim günden beri müdürümün benimle ilgili düşünceleri } \\
\text { değişmedi. }\end{array}$ & & \\
\hline & $\begin{array}{l}\text { Ne yaparsan yapayım kendimi beğendiremiyorum. Adım çıkmış bi } \\
\text { kere. }\end{array}$ & & \\
\hline & $\begin{array}{l}\text { Öğretmenleri şucu bucu diye fişlerseniz ve okula bu gözle bakarsanız, } \\
\text { okul olur size hapishane. }\end{array}$ & & \\
\hline & Yöneticilerimiz önyargılarından arınabilse okul daha başarılı olacak. & & \\
\hline & $\begin{array}{l}\text { Öğretmene önyarg1, veliye önyarg1, öğrenciye ön yarg1 sanki kendileri } \\
\text { sütten çıkmış ak kaşık. }\end{array}$ & & \\
\hline \multicolumn{2}{|l|}{ Toplam } & & 100 \\
\hline
\end{tabular}

Okul yöneticilerinin önyargılı olmama becerilerinin yeterli olduğu yönünde görüş bildiren K 10 rumuzlu katılımcı "şükürler olsun müdürlerimiz önyargılı insanlar değil. Herkes barış içerisinde güvenli bir ortamda çalışlyor” ifadelerini kullanırken bu konuda okul müdürlerinin kısmen yeterli olduklarını düşünen K 9 rumuzlu katılımcı “menfaatler söz konusu değilse okul yöneticilerimiz tarafsız olabiliyor. Ancak çatışma yaşadığımız zaman aynı şeyleri söyleyemem. Hemen silahlar çekiliyor ve konu önyargı ile birlikte kişiselleştiriliyor" söyleminde bulunmuş, bu konuda okul müdürünün yetersiz olduğunu düşünen K 9 rumuzlu katılımc1 ise "okul müdürümüzün önyargıları nedeniyle herkes okula sırt çevirdi. Her söyleminde hissedilen bu düşmanca tutum okulun düzenini bozuyor” şeklinde düşüncelerini dile getirmiştir. 


\section{Okul yöneticilerinin iletişimde planlı davranma becerilerine ilişkin} öğretmen görüş̧leri. Tablo 9'da okul yöneticilerinin iletişimde planlı davranma becerilerine ilişkin öğretmen görüşleri sunulmuştur.

\section{Tablo 9}

Okul yöneticilerinin iletişimde planl davranma becerilerine ilişkin öğretmen görüşleri

Planlama $\quad f \quad \%$

Okul müdürümüz, özellikle toplantılarda kendisini başarılı bir şekilde ifade ediyor. Bu da planlı ve programlı olduğunu gösteriyor.

Okulda yapılan işler aksamıyor. Müdürümüz bu konularda iyi düşünerek hareket ediyor.

Yeterli Müdürümüz bizden bir şeyler talep ederken, mutlaka geçerli nedenler $\quad \begin{aligned} & 5 \\ & 25\end{aligned}$ öne sürüyor.

Yöneticimiz bize net mesajlar veriyor.

Müdürümüz kafa karışıklığı oluşturmamak için azami gayret gösteriyor.

Planlama noktasında okulda sağlıklı bir ortam olduğunu düşünmüyorum. İşler bazen iyi bazen kötü gidiyor.

Yöneticilerin planlı programlı davranmaları gerekir. Ama çoğunlukla

Kismen yeterli bu konuda aksaklıklar yaşanıyor.

Bürokratik işlerde planlı olunurken, öğretmen ve öğrenci başarısında saldım çayıra mevlam kayıra durumu söz konusu.

"Planlı olmak başarı getirir" diyen müdürümüzde planlı olma konusunda yeterince gayret göremedim.

Okulda plan ya da programdan bahsetmek mümkün değil. Bu konuda büyük bir yönetim zafiyeti var.

Müdürümün taleplerini anlamak için yoğun bir çaba harcıyorum. Bize her türlü talep çok dağınık geliyor.

Toplantılarda bile yapılacak çalışmaların planlanması yapışmıyorsa,

Yetersiz gerisi siz düşünün artık.

Okulumuz da genel anlamda bir plansızlık söz konusu. Bu nedenle çay bile içemiyoruz.

Görev dağılımında yapılan hatalar plansızlığı ve iletişimdeki eksikliklerin bir göstergesi olabilir.

Ders programı yapılırken bari bizim isteklerimizi sorun. Yok işte kafalarına göre takılıyorlar.

Tablo 9'a göre öğretmenler, okul yöneticilerinin planlama becerilerine ilişkin olarak \% 25 oranında yeterli $(f=5), \% 20$ oranında kısmen yeterli $(f=4)$ ve \%55 oranında yetersiz ( $\mathrm{f}=11$ ) şeklinde görüş bildirmişlerdir. Verilen cevaplar 
incelendiğinde: Okul yöneticilerinin planlama becerilerinin yeterli düzeyde olduğu yönünde görüş bildiren öğretmenler, okul yöneticisi tarafindan açık ve net mesajlar verildiği, toplantılarda gerekli açıklamaların yapıldığı, taleplerin geçerli nedenlere dayandırıldığı ve okulda işlerin başarılı bir şekilde gerçekleştiği konuları üzerinde; kısmen yeterli yönünde görüş bildiren öğretmenler, planlama konusunda yöneticilerin yeterince gayret göstermediği, bazı işlerin aksadığı ve planlamanın sadece evraklar üzerinde gerçekleştiği konuları üzerinde; yetersiz yönünde görüş bildiren öğretmenler ise bu konuda büyük bir yönetim zafiyetinin olduğu, yöneticinin taleplerinin anlaşılmadığı, görev dağılımının ve ders programlarının ilgililere sorulmadan yapıldı̆̆ konuları üzerinde durmuşlardır. Elde edilen bulgulara dayanılarak öğretmenlerin, okul yöneticilerinin planlama beceri düzeylerini genel olarak yetersiz buldukları söylenebilir.

Okul yöneticilerinin planlama becerilerinin yeterli olduğu yönünde görüş bildiren K 10 rumuzlu katılımcı "müdürümüz planlama konusunda oldukça başarılı. Bir konuda hazırlık yapmadan kesinlikle bizimle iletişim kurmaz" ifadelerini kullanırken bu konuda okul müdürlerinin kısmen yeterli olduklarını düşünen K 9 rumuzlu katılımcı “okulda planlama sadece bürokratik olarak işliyor. Diğer bütün işler özellikle ögrrenci başarısı ve ögretmen verimliliği plansız ve programsız devam ediyor” söyleminde bulunmuş, bu konuda okul müdürünün yetersiz olduğunu düşünen K 9 rumuzlu katılımc1 ise "okuldaki plansızlık bütün işleri aksatıyor. Müdürümüz alt yapısını hazırlamadan bizden bir takım işler talep ediyor. Anlamıyoruz, anlamsız geliyor" şeklinde düşüncelerini dile getirmiştir.

\section{Sonuç ve Tartışma}

Araştırmada, okul yöneticilerinin iletişim becerileri ölçeği ve alt boyutlanı seçeneklere göre kodlanan puan aralığı (SKPA) dikkate alınarak değerlendirildiğinde, öğretmenlerin empatik düşünme, bilgi aktarımı ve olumlu tutumlar boyutunu "tamamen kat1lıyorum" düzeyinde; önyargılı olmama ve planlama boyutunu "katılıyorum" düzeyinde; okul yöneticilerinin iletişim becerileri ölçeğini toplamda ise "tamamen katılıyorum" düzeyinde algıladıkları görülmektedir. Okul yöneticilerinin iletişim becerileri ölçeğinden alınan toplam puanın "tamamen katılıyorum" düzeyinde olması ise öğretmenlerin, okul yöneticilerinin iletişim becerilerini toplamda yüksek düzeyde yeterli algıladıklarını göstermektedir. Alan yazında okul yöneticilerinin iletişim becerileri ile ilgili bulguların yapılan araştırmaların içeriğine bağlı olarak farklı şekillerde ifade edildiği görülmektedir. Konu ile ilgili yapılan araştırmalarda öğretmen görüşlerine göre okul yöneticilerinin iletişim becerilerinin Çetinkaya (2011) orta düzeyde olduğunu; Önsal (2012) etkili fakat geliştirilmesi gereken düzeyde olduğunu; Gürsun (2007) ara sıra algısına bağlı olarak düşük düzeyde olduğunu; Şahin (2007) yüksek düzeyde olduğunu; Çelik (2013) 4.188 ortalamasına bağlı olarak yüksek düzeyde olduğunu; Fidan (2013) 3.45 ortalama ile kat1lyyorum düzeyinde olduğunu; Lal (2012) aritmetik ortalamalar sonucunda 3 okulun (C, D, J) “üst düzeyde etkili” iletişim becerisine sahip olduğunu; Şimşek ve Altınkurt (2009) genel olarak etkili bulunduğunu ancak bu becerilerin geliştirilmesi gerektiğini belirtmişlerdir. Sevinç (2013) konuyla ilgili bulguları yöneticilerin “anlama-empati kurabilme” ve “sosyal 
rahatlık" boyutlarında yüksek düzeyde iletişim yeterliğine sahip oldukları, "destekleme" boyutunda ise orta düzeyde iletişim yeterliğine sahip oldukları şeklinde boyutlar bazında verirken, Çetinkaya (2012) ilköğretim okulu yöneticilerinin 24’ünün (\% 68.57) “üst düzeyde etkili”, 9'unun (\% 25.71) “etkili fakat geliştirilmesi gereken” ve 2'sinin (\% 5.71) "vasat" iletişim becerisine sahip olduklarını ifade etmiştir. Şimsek (2003) ise okul müdürlerinin \% 25 'inin üst düzeyde etkili iletişim becerilerine ve \% 75'inin ise etkili fakat geliştirilmesi gereken iletişim becerilerine sahip oldukları bulgularına ulaşmıştır. Çelik (2008), Çetinkaya (2011) ve Şahin (2007) araştırmalarında okul yöneticilerinin iletişim becerilerini hem öğretmen hem de yönetici algılarına göre değerlendirmiş ve okul yöneticilerinin öğretmenlere göre kendi iletişim becerilerini daha yüksek algıladıkları sonucuna ulaşmışlardır. Bir başka araştırma da Durgun (2011) okul yöneticilerinin yönetici-yönetici iletişimlerinin sorunsuz olduğu bulgusuna ulaş1lırken, yönetici-öğretmen, yönetici-öğrenci ve yönetici-veli iletişimlerinde önemli sorunlar olduğu saptamıştır. Araştırma sonuçlarında da görüldüğü üzere öğretmenler büyük çoğunlukla yöneticilerin iletişim becerilerini yeterli olarak algılamaktadır. Ancak Köleşoğlu'nun (2009) araştırmasında ulaştığı öğretmenlerin kendi iletişim becerilerini orta düzeyde algıladığı bulgusunun öğretmenlerin okul yöneticilerinin iletişim becerilerini algilama biçimleriyle tezat oluşturduğu söylenebilir.

Öğretmenlerin, okul yöneticilerinin iletişim becerilerine ilişkin algılarının ortalamaları kıdem, branş ve cinsiyet değişkenlerine göre $(\bar{x}=4.21)$ ile $(\bar{x}=4.40)$ aralığında değişmektedir. Seçeneklere göre kodlanan puan aralığına (SKPA) göre öğretmenlerin, ilgili değişkenlerin tümünde, okul yöneticilerinin iletişim becerilerine ilişkin algıları “ tamamen katılıyorum” düzeyindedir. En yüksek ortalama ( $\bar{x}=4.40)$ ile kıdem değişkeninin "1-5 y1l” aralığında iken en düşük ortalama $(\bar{x}=4.21)$ ile branş değişkeninin "sosyal bilgiler” branşında yer almaktadır. Öğretmenlerin okul yöneticilerinin iletişim becerilerine ilişkin algılarının tüm değişkenlerde "tamamen katılıyorum" düzeyinde olması, ortaokullarda görev yapan branş öğretmenlerinin ilgili değişkenlerde benzer alg1 puanlarına sahip olduklarını göstermektedir. Ancak alan yazında okul yöneticilerinin iletişim becerilerine ilişkin görüş belirten öğretmenlerin Tek (2008) yaş ve yöneticilik kıdemi; Cesur (2009) bulundukları okuldaki görev süresi; Bektaş (2010) mesleki kıdeme ve öğrenim durumu; Çelik (2008) kıdem, yaş, öğrenim durumu ve okulun bulunduğu sosyoekonomik çevre; Çalışgan (2006) cinsiyet, mesleki kıdem, eğitim düzeyi, okul imkanları ve iletişim eğitimi alma durumları; Sevinç (2013) cinsiyet; Şimşek ve Altınkurt (2009) hizmet süresi ve cinsiyet; Çetinkaya (2012) yaş, öğrenim durumu, kıdem ve branş değişkenlerine göre anlamlı farklılıklar bulunmuştur.

Araştırmanın nitel bulgularında öğretmenlere yöneltilen açık uçlu sorulardan elde edilen cevaplar "yeterli", "kısmen yeterli" ve "yetersiz" şeklinde kategorilere ayrilarak incelenmiştir. Buna göre öğretmenler, okul yöneticilerinin iletişim becerilerini genel olarak \% 35 oranında yeterli; empatik düşünme becerilerini \% 30 oranında yeterli; bilgi aktarımı becerilerini \%45 oranında yeterli; önyargılı olmama becerilerini \% 40 oranında yeterli olarak değerlendirmişlerdir. Bilgi aktarımı ve önyargılı olmama becerilerinde okul yöneticilerinin yeterli oldukları algısı oran olarak en yüksek yüzdeye sahip olsa da 
nitel bulgulardan elde edilen yönetici iletişim beceri düzeyinin genel olarak düşük düzeyde olduğu görülmektedir. Alan yazında okul yöneticilerinin iletişim becerileri ile ilgili nitel bir çalışmaya rastlanmazken konuyla ilgili yapılan nicel çalışmalarda ise sadece Gürsun (2007) ara sıra algısına bağlı olarak okul yöneticilerinin iletişim becerisinin düşük düzeyde olduğu ve Durgun (2011) okul yöneticilerinin yöneticiyönetici iletişimlerinin sorunsuz olduğu, yönetici-öğretmen, yönetici-öğrenci ve yönetici-veli iletişimlerinde önemli sorunlar olduğu bulguları ile bu çalışmanın nitel bulguları örtüşmektedir. Bu çalışmaların dışında nitel bulgular hem bu araştırma sonuçlarıyla hem de genel olarak alan yazında bulunan araştırma sonuçlarıyla örtüşmemektedir. Nitel bulguların nicel bulguları büyük oranda desteklememesi ve nitel bulguların araştırmada kullanılan açıklayıcı desenin kapsamına göre nicel bulguları tam olarak açıklamaması nitel ve nicel yöntemde kullanılan farklı soru biçimlerine bağlanabilir. Buna göre araştırmanın nicel bölümünde yöneltilen yapılandırılmış likert tipli ölçek sorularında katılımcıların konuyla ilgili kendilerini tam olarak ifade edemedikleri, yarı yapılandırılmış nitel sorular ile yapılmış karşılıklı görüşmelerde ise kendilerini daha iyi ifade ettikleri, nitel ve nicel bulgular arasındaki farklılıkların ise bu nedene bağlı olarak ortaya çıkmış olabileceği söylenebilir. Nitel ve nicel bulguların birbirini desteklememesi öğretmen algılarına göre okul yöneticilerinin iletişim becerilerinde sorunlar olduğunun bir göstergesi olarak kabul edilebilir. Bu nedenle okul yöneticilerinin muhatabına karşı duyarlı olup empati yapabilen (Karsl1, 2006), sınıf içi ziyaret, teftiş, görüşme ve toplantı gibi faaliyetleri yürüten (Şişman, 2002), okuldaki öğretmenlerini çok iyi tanıyan (Toprakçı, 2008), iletişim vasıtasıyla öğretmen motivasyonunu arttıran (Gürsel, 1997), etrafındaki insanların taleplerine duyarlı olabilen (Büyükçolak, 1997), sıcak, destekleyici ve yardım edici tarzda iletişim sağlayabilen (Marşap, 1999) ve sempati duygularıyla iletişim kurmaya özen gösteren (Schmidt \& Tannenbaum, 2000), öğretmenler dışında velileri ve diğer paydaşları gözeten (Goldring, 2002), öğretmenler ile riskten uzak ve şeffaf bir ilişki kuran (Rafferty, 2003), insan ilişkileri alanında kendisini geliştirmiş olan (Ünal, 2000), kişiler arasından seçilmesi gerektiği söylenebilir.

\section{Öneriler}

Araştırma bulguları kapsamında;

1- Okul yöneticilerinin iletişim becerileri konusunda, farklı örneklem grupları üzerinde, nitel ve karma desende yapılandırılmış çalışmaların yapılması,

2- $\mathrm{Bu}$ araştırma kapsamında nitel ve nicel bulguların örtüşmediği sonucuna bağlı olarak, bu sonucun nedenlerini tespit etmeye yönelik çalışmaların yapılması,

3- 6528 sayılı kanun gereğince okul yöneticilerinin seçimi ve atanmasıyla ilgili çıkartılacak yönetmelikte okul yöneticileri ile ilgili kriterler arasına insan ilişkileri ve iletişim konularında eğitim almış olma kriterinin getirilmesi,

4- 6528 sayılı kanun gereğince okul yöneticilerinin seçimi ve atanmasıyla ilgili çıkartılacak yönetmelikte okul yöneticileri ile mülakat yapacak kişiler arasında iletişim konusunda uzman akademisyenlerin bulunmasının sağlanması, 
5- İletişimin tek taraflı olmamasına bağlı olarak okul yöneticilerinin iletişim konusunda daha iyi denetlenebilmesi ve okul yöneticilerinin iletişim konusunda kendilerini geliştirebilmeleri amaciyla öğretmenlere ve diğer MEB personeline iletişim becerileri konusunda eğitimlerin verilmesi önerilebilir.

\section{Kaynakça}

Adair, J. (2004). Etkili iletişim (2.Baskı). İstanbul: Babıali Kültür Yayıncılığı.

Argon, T., \& Zafer, D. (2009). İlköğretim okulu yöneticilerinin iletişim sürecinde yaşadıkları problemler. Sakarya University Journal of Educational Faculty, 18, 99123.

Ärlestig, H. (2007). Principals' communication inside schools: a contribution to school 1mprovement? The Educational Forum, 71(3), 262-273.

Aslanargun, E. \& Bozkurt, S. (2012). Okul müdürü-öğretmen iletişimi ve ortaya çıkan sorunlar. Gaziantep University-Journal of Social Sciences, 11(2), 349-368.

Aydın, M. (2010). Eğitim yönetimi (9. Baskı). Ankara: Hatiboğlu Yayıncılık.

Aydoğan, İ. \& Kaşkaya, A. (2010). İlköğretim okulu yöneticilerinin iletişim becerilerinin yönetici ve öğretmen görüsslerine göre değerlendirilmesi. Gazi University Journal of Gazi Educational Faculty (GUJGEF), 30(1), 1-16.

Başaran, İ.E. (2000). Örgütsel davranış. Ankara: Feryal Matbaası.

Bektaş, A. (2010). Illköğretim okulu yöneticilerinin sosyal iletişim becerileri ile ögretmen motivasyonu arasındaki ilişki (Yayımlanmamış yüksek lisans tezi). Gazi Üniversitesi, Eğitim Bilimleri Enstitüsü, Ankara.

Bilgin, N. (2006). Sosyal bilimlerde içerik analizi (2. Bask1). Ankara: Siyasal Yayıncilık.

Bursalığlu, Z. (2010). Okul yönetiminde yeni yapı ve davranış. Ankara: Pegem A Yayıncilik.

Büyükçolak, K. M. (1997). Bilgi çağında liderlik. 21.Yüzyılda Liderlik Sempozyumu, 56 Haziran 1997 (syf. 321-326). İstanbul: Deniz Harp Okulu.

Büyüköztürk, Ş., Çakmak, E.K., Akgün, K.Ş., \& Demirel, F. (2012). Bilimsel araştırma yöntemleri. (12. Basım). Ankara: Pegem A Yayıncılık.

Büyüköztürk, Ş. (2010). Sosyal bilimler için veri analizi el kitabı. Ankara: Pegem Yayınc1lik.

Celep, C. (2000). Eğitimde örgütsel adanma ve öğretmenler. Ankara: Anı Yayıncılık.

Cesur, H. (2009). Ortaöğretim müdürlerinin liderlik stilleri ve iletişim becerileri arasındaki ilişkinin ögretmen algılarına göre değerlendirilmesi (Yayımlanmamış yüksek lisans tezi). Yeditepe Üniversitesi, Sosyal Bilimler Enstitüsü, İstanbul.

Cüceloğlu, D. (1997). Yeniden insan insana (14. Basım). İstanbul: Remzi Kitabevi.

Çelik, Ç. (2008). Illköğretim okulu müdürlerinin iletişim becerileri ile tükenmişlik düzeyleri arasındaki ilişki (Yayımlanmamış yüksek lisans tezi). Gaziantep Üniversitesi, Sosyal Bilimler Enstitüsü, Gaziantep. 
Çelik, M. (2013). İstanbul İli Arnavutköy ilçesindeki ortaöğretim kurumlarında görev yapan yöneticilerin iletişim becerilerinin öğretmen motivasyonları ve akademik tükenmişlikleri üzerine etkisi (Yayımlanmamış yüksek lisans tezi). Yeditepe Üniversitesi, Sosyal Bilimler Enstitüsü, İstanbul.

Çetinkaya, İ. (2011). Ortaöğretim okul müdürlerinin liderlik stilleri ve iletişim becerileri arasındaki ilişki (Yayımlanmamış yüksek lisans tezi). Gazi Üniversitesi, Eğitim Bilimleri Enstitüsü, Ankara.

Çetinkaya, H. (2012). İlköğretim okulu yöneticilerinin iletişim becerilerinin okul başarısına etkisi (Yayımlanmamış yüksek lisans tezi). Anadolu Üniversitesi Eğitim Bilimleri Enstitüsü, Eskişehir.

Çalışgan, H. (2006). Okul yöneticilerinin iletişim becerilerinin öğretmenlerin kişisel özellikleri açısından değerlendirilmesi (Yayımlanmamış yüksek lisans tezi). Yeditepe Üniversitesi, Sosyal Bilimler Enstitüsü, İstanbul.

Demir, K. (2005). İl Milli Eğitim Müdürlüğü yönetim bilgi sistemlerinin incelenmesi. Kuram ve Uygulamada Eğitim Yönetimi Dergisi, 36, 558-581.

Dökmen, Ü. (2005). Küçük şeyler (3. Bask1). İstanbul: Sistem Yayıncılık.

Durmuş, B., Yurtkoru, E.S., \& Çinko, M. (2011). Sosyal bilimlerde SPPS'le veri analizi. İstanbul: Beta Yayıncılık.

Durukan, H. (2003). Yönetimde insan ilişkileri. Kastamonu Ĕgitim Fakültesi Dergisi, 11 (2) , 277-284.

Doğan, S., Uğurlu, C. T., Yıldırım, T., \& Karabulut, E. (2014). Okul yöneticileri ve öğretmenler arasındaki iletişim sürecinin öğretmen görüşlerine göre incelenmesi. Turkish Journal of Education, 3(1), 34-47.

Doğuş, Y. (2011) Okul yöneticileri ve öğretmenlerin bakışı ile empatik iletişim. eJournal of New World Sciences Academy, 6(1), 696-707.

Durgun, S. (2011). Genel ortaöğretim kurumlarında görev yapan yöneticilerin örgüt içi iletişim sürecinde yaşadıkları sorunlar ve bu sorunlarla başa çıkma yolları. Pegem Ĕ̈itim ve Öğretim Dergisi, 1(2), 57-68.

Ergin, A. (2012). Ĕğitimde etkili iletişim (6. Baskı). Ankara: Anı Yayıncılık.

Ergin, A. (1998). Öğretim teknolojisi iletişim (2. Bask1). Ankara : Anı Yayıncılık.

Fidan, M. (2013). Öğretmen algllarına göre ilköğretim kurumlarında yöneticilerin iletişim becerileri ve örgütsel değerler arasındaki ilişki (Yayımlanmamış yüksek lisans tezi). Atatürk Üniversitesi, Eğitim Bilimleri Enstitüsü, Erzurum.

Goldring, L. (2002). The power of school culture. Leadership, 32(2), 32-35.

Gümüş, S. (2009). İlköğretim öğretmenlerinin liderlik özellikleri ile iletişim becerileri arasındaki ilişki: İstanbul ili Beyoğlu ilköğretim okullarında bir uygulama (Yayımlanmamış yüksek lisans tezi). Beykent Üniversitesi, Sosyal Bilimler Enstitüsü, İstanbul.

Gürsel, M. (1997). Okul yönetimi. Konya: Mikro Yayınları.

Gürgen, H. (1997). Örgütlerde iletişim kalitesi. İstanbul: Der Yayınları. 
Gürsun, Y. (2007). İlköğretim okul müdürlerinin öğretmenler tarafindan algllanan ögretimsel liderlik rolleri ile iletişim tarzları arasındaki ilişkinin incelenmesi (Yayımlanmamış yüksek lisans tezi). Yeditepe Üniversitesi, Sosyal Bilimler Enstitüsü, İstanbul.

Halawah, I. (2005). The relationship between effective communication of high school principal and school climate. Education, 126(2), 334-345.

Karasar, N. (2011). Bilimsel araştırma yöntemi (16. Baskı). Ankara: Nobel Yayıncılık.

Karsl1, M.D. (2006). Etkili okul yöneticiliği. İstanbul: Morpa Yayıncılık.

Korkmaz, M. (1995). Okul yönetiminde çatışma. Çağdaş Eğitim, 20(207), 26-29.

Köleşoğlu, G. (2009). İlköğretim öğretmenlerinin liderlik özellikleri ile iletişim becerileri arasındaki ilişki (Yayımlanmamış Yüksek Lisans Tezi). Beykent Üniversitesi Sosyal Bilimler Enstitüsü, İstanbul.

Lal, İ. (2012). İlköğretim okulu müdürlerinin iletişim becerileri ile okul kültürü arasındaki ilişkiler (Yayımlanmamış yüksek lisans tezi). Ahi Evran Üniversitesi, Sosyal Bilimler Enstitüsü, Kırşehir.

Marşap, A. (1999). Yaratıcı liderlik. Ankara: Öncü Kitapevi

Marzano, R. J., Waters, T., \& McNulty, B. A. (2005). School leadership that works: From research to results. Alexandria, VA: Association for Supervision and Curriculum Development.

Mills, G. E. (2003). Action research a guide for the teacher researcher (2 nd. edition). Pearson Education, Boston.

Miles, M. B., \& Huberman, A. M. (1994). Qualitative data analysis: An expanded sourcebook. London: Sage.

Myran, S., Sanzo, K., \& Clayton, J. (2011). The school leadership program communication hub: building actionable knowledge about improving leadership preparation. International Journal of Educational Leadership Preparation, 6(3), 112.

Neves de Jesus, S. \& Lens, W. (2005). An integrated model for the study of teacher motivation. Applied Psychology, 54(1), 119-134.

Önsal, A. (2012). Okul müdürlerinin iletişim becerileri ile okul kültürü arasındaki ilişki(İstanbul ili Anadolu yakası örneği) (Yayımlanmamış yüksek lisans tezi). Maltepe Üniversitesi / Sosyal Bilimler Enstitüsü, İstanbul.

Özan, M. B. (2006). İlköğretim okulu yöneticilerinin iletişim becerilerinin öğretmen ve yönetici bakış açısıyla değerlendirilmesi. Eurasian Journal of Educational Research (EJER), 24.

Rafferty, T. J. (2003). School climate and teacher attitudes toward upward communication in secondary schools . American Secondary Education, 31(2), 4970.

Rowicki, M. A. (1999). Communication skills for educational administrators. Eric ED 432 830EA. 1-9. 
Sayers, F., Bingaman, C.E., Graham, R., \& Wheeler, M. (1993). Yöneticilikte iletişim.(Çev: Doğan Şahiner). İstanbul: Rota Yayıncılık.

Schein, E. H. (1976). Örgütsel psikoloji (2. Bask1) (Çeviren: Aylin Sağtür-Şan ÖzAlp). Eskişehir: Eskişehir İktisadi ve Ticari Bilimler Akademisi Basımevi.

Sevinç, Y.S. (2013). Ilköğretim okulu yöneticilerinin iletişim yeterliliklerine ilişkin ögretmen görüşleri ile öğretmenlerin örgütsel güven düzeyleri arasındaki ilişki (Yayımlanmamış yüksek lisans tezi). Uşak Üniversitesi Sosyal Bilimler Enstitüsü, Uşak.

Schmidt, H. W., \& Tannenbaum, R. (2000). Farklllıkları yönetmek (Çev ed. İbrahim Bingöl.) İstanbul: Mess Yayınları.

Sönmez, V., \& Alacapınar, G. F. (2011). Örneklendirilmiş bilimsel araştırma yöntemleri. Ankara: Anı yayınc1lık.

Şahin, A. (2007). İlköğretim okulu yöneticilerinin kişiler arası iletişim becerileri ve çatışma yönetimi stratejileri arasındaki ilişki (Yayımlanmamış yüksek lisans tezi). Akdeniz Üniversitesi, Sosyal Bilimler Enstitüsü, Antalya.

Şişman, M. (2003). Öğretmenlik mesleğine giriş. Ankara: Pegem A Yayıncılık.

Şişman, M. (2002). Öğretim liderliği. Ankara: Pegem A Yayıncılık.

Şimşek, Y. (2003). Okul müdürlerinin iletişim becerileri ile okul kültürü arasındaki ilişki (Yayımlanmamış doktora tezi). Anadolu Üniversitesi Eğitim Bilimleri Enstitüsü, Eskişehir.

Şimşek, Y., \& Altınkurt, Y. (2009). Endüstri meslek liselerinde görev yapan öğretmenlerin okul müdürlerinin iletişim becerilerine ilişkin görüşleri. Akademik Bakış, (17), 1-16.

Yazıcıoğlu, Y., \& Erdoğan, S. (2004). SPSS uygulamalı bilimsel araştırma yöntemleri. Ankara: Detay Yayıncılık.

Y1ldırım, A., \& Şimşek, H. (2011). Sosyal bilimlerde nitel araştırma yöntemleri. (8. Baskı). Ankara: Seçkin Yayıncılık.

Tavşanc1l, E., \& Aslan, E. (2001). Sözel, yazılı ve diğer materyaller için içerik analizi ve uygulama örnekleri. Ankara: Epsilon.

Tek, İ.(2008). Okul yöneticilerinin iletişim becerisi ile çatışmayı yönetme becerileri arasındaki ilişkinin incelenmesi (İstanbul Kadıköy ilçesi örneği). (Yayımlanmamış yüksek lisans tezi). Yeditepe Üniversitesi, Sosyal Bilimler Enstitüsü, İstanbul.

Toprakçı, E. (2008). Sınıfa dayalı yönetim. Ankara: Pegem Akademi Yayıncılık.

Tutar, H., \& Yılmaz, M.K. (2008). Genel iletişim kavramlar ve modeller (6. Bask1). Ankara: Seçkin Yayıncılık.

Ünal, S. (2000). İlköğretim okulu yöneticilerinin okullarında motivasyonu sağlama etkinlikleri. Pamukkale Üniversitesi Eğitim Fakültesi Dergisi, 1, 84-90.

Zıllığlu, M. (2003). Illetişim nedir? (2. Basım). İstanbul: Cem Yayınevi. 